\title{
Working
}

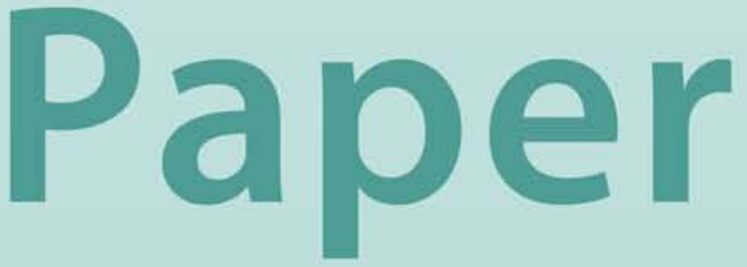


Capital Flows to Central and Eastern Europe Philip R. Lane and Gian Maria Milesi-Ferretti 


\title{
IMF Working Paper
}

\author{
Research Department
}

\section{Capital Flows to Central and Eastern Europe}

\section{Prepared by Philip R. Lane and Gian Maria Milesi-Ferretti ${ }^{1}$}

August 2006

\begin{abstract}
This Working Paper should not be reported as representing the views of the IMF. The views expressed in this Working Paper are those of the author(s) and do not necessarily represent those of the IMF or IMF policy. Working Papers describe research in progress by the author(s) and are published to elicit comments and to further debate.

We examine the evolution of the net external asset positions of Central and Eastern Europe (CEEC) countries over the past decade, with a strong emphasis on the composition of their international balance sheets. We assess the extent of their international financial integration, compared with the advanced economies and other emerging markets, and highlight the salient features of their external capital structure in terms of the relative importance of FDI, portfolio equity, and external debt. In addition, we briefly describe the country and currency composition of their external liabilities. Finally, we explore the implications of the accumulated stock of external liabilities for future trade and current account balances.
\end{abstract}

JEL Classification Numbers: F32; F34

Keywords: Trade balance, rates of return, net external position, FDI

Author(s) E-Mail Address: plane@tcd.ie; gmilesiferretti@imf.org

\footnotetext{
${ }^{1}$ This paper was prepared for the conference "Labor and Capital Flows in Europe Following Enlargement," held in Warsaw on January 30-31, 2006. We thank our discussant, Jean Pisani-Ferry, conference participants, Mark Lutz, Ashoka Mody, and Franek Rozwadowski for useful comments. We are also grateful to David Robinson for suggesting the key assumption about rates of return on FDI. Agustín Bénétrix and Vahagn Galstyan provided excellent research assistance. Lane thanks the IRCHSS and the HEA-PRTLI grant to the IIIS for financial support.
} 
I. Introduction

II. The Main Stylized Facts: Aggregate Data

A. Trends in the Current Account and Net External Positions .................................... 4

B. International Financial Integration ................................................................

C. Portfolio Composition .......................................................................................

III. The Main Stylized Facts: Bilateral Data ................................................................. $\underline{8}$

IV. Capital Flows and External Adjustment ............................................................10

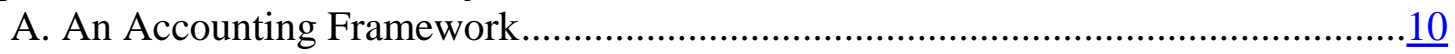

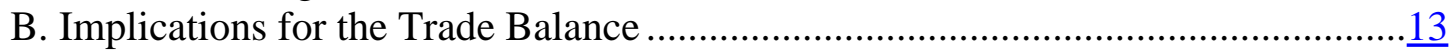

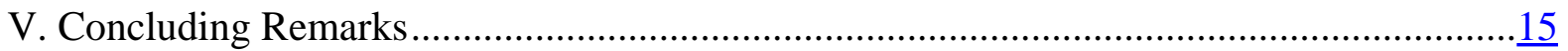

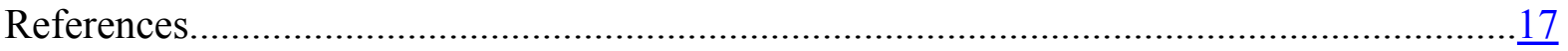

Tables

1A. Central and Eastern European Countries: Foreign Direct Investment Sources ............19

1B. Central and Eastern European Countries: Sources of Portfolio Equity Investment .... $\underline{19}$

1C. Central and Eastern European Countries: Sources of Foreign Bank Assets.................20

1D. Central and Eastern European Countries: Sources of Portfolio Debt Investment .......20

2. Currency Composition of International Bond Issues.............................................. 21

3 Composition of Net External Position (in percent of GDP), 2004 ...........................22

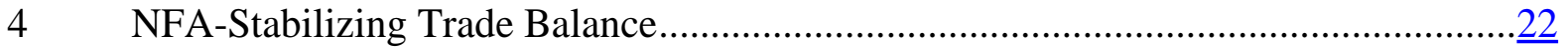

Figures

1. Net External Position, Developing Countries and Emerging Markets, 1994 ..............23

2. Net External Position, Developing Countries and Emerging Markets, 2004 ..............24

3. International Financial Integration: Central and Eastern European Countries,

EU-15 Group, and Other Emerging Markets, 1993-2004 …............................25

4. Composition of External Liabilities: Share of Total Equity Liabilities,

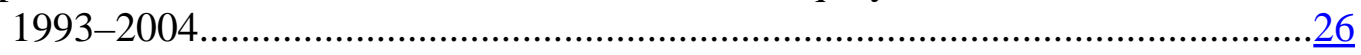

5. Composition of External Liabilities: Share of Foreign Direct Investment

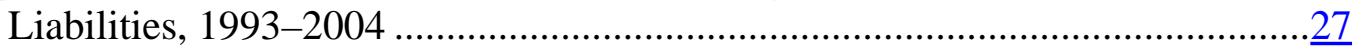

6. Composition of External Assets: Central and Eastern European Countries,

EU-15, and Other Emerging and Developing Economies, 1993-2004 ..............28

7. Central and Eastern European Countries: Net Equity and Net Debt

Position, 2004 


\section{INTRODUCTION}

The last 15 years have witnessed dramatic changes in the Central and Eastern Europe countries (CEECC). They all have been the recipients of substantial net capital flows, as befits their overall capital scarcity, relatively high initial levels of human capital, and the institutional anchor of actual or potential membership of the European Union (EU). While overall output performance during this period is still conditioned by the initial output decline, growth rates in several CEEC countries during the past decade have been high by emerging market standards.

The accumulation of external liabilities can accelerate the growth convergence process and allow a fast-growing country to exploit investment opportunities while raising its consumption level in advance of increases in its income. For countries that are making substantial recourse to foreign capital, two important issues arise. First, as the burden of investment income and principal repayments increases over time, borrowing countries need to ensure that trade surpluses allow the external position to stabilize or decline, relative to the size of the economy. The size of the needed trade surpluses depends not only on the outstanding stock of accumulated liabilities and the rate of output growth, but also on the expected rates of return on a country's foreign assets and liabilities, which will be heavily influenced by the composition of its international balance sheet.

A second important issue for an indebted economy is an assessment of its degree of vulnerability to financial shocks. For instance, the international financial crises of the 1990s highlighted the potential volatility involved with a heavy reliance on certain types of external finance, especially short-term foreign-currency debt. For this reason, it is also important to understand the risk profile of a country’s international financial liabilities.

Accordingly, this paper focuses on the evolution of the external position in CEEC countries over the past decade, with a strong emphasis on the composition of the international balance sheet. It assesses the extent of their international financial integration, in comparison to the advanced economies and other emerging markets. It also highlights the most salient features of their external capital structure in terms of the relative importance of foreign direct investment (FDI), portfolio equity, and debt categories in the overall level of external liabilities. In addition, it briefly describes the bilateral and currency composition of their external liabilities. These stylized facts are used to explore the implications of the accumulated stock of external liabilities for future trade and current account balances.

Our data analysis highlights the large accumulation of net external liabilities in several CEECs during the past decade, in contrast with trends in other emerging markets. In contrast to previous episodes of high net capital flows to some emerging markets (such as Latin America in the late 1970s and early 1990s), we find that direct investment flows have been especially prominent in financing external current account imbalances in the CEEC. While equity-type flows allow the borrowing country to share risk with foreign investors more 
effectively than foreign-currency debt, because the profitability of FDI is likely to be linked to the performance of the domestic economy, the rate of return on external liabilities can actually be higher than the rate of return on debt, to the extent that direct investors require an equity premium. In terms of bilateral patterns, there are strong geographic factors driving capital flows, with Western European countries the dominant external investors in this region and the United States only significant for portfolio equity flows.

Looking to the medium term, we calculate that CEECs will have to run (relatively modest) future surpluses on their balance of goods, services, and transfers to stabilize their net external position. Nevertheless, given the large trade deficits several of these countries are currently running, the needed shift in the trade balance is substantial, particularly for the Baltic countries, Bulgaria, and Romania. Faster export growth, lower spreads on external debt, higher EU transfers, and higher labor remittances can all contribute to the needed external adjustment.

The structure of the rest of the paper is as follows. We present the main stylized facts concerning the aggregate net and gross external positions in Section II, followed by a description of the bilateral and currency composition of their external liabilities in Section III. We turn to an analysis of external adjustment dynamics in Section IV, presenting an accounting framework and making some projections for the future path for the trade balance as a function of some key parameters. Section V offers some concluding remarks, drawing out the policy implications of our analysis.

\section{The Main Stylized Facts: Aggregate Data}

In this section we provide some stylized facts on the external portfolio of countries in Central and Eastern Europe. In particular, we compare the situation at end-2004-the most recent data currently available-with the situation one decade earlier, in the early stages of the transition process. To put these facts in context, we compare these countries with other emerging and developing economies, as well as to the EU-15 countries.

\section{A. Trends in the Current Account and Net External Positions}

Figure 1 provides a simple illustrative scatter plot of the net external position in developing countries and emerging markets at the end of 1994, depicting net external assets (as a percent of GDP) together with GDP per capita. Three of the CEECs in the region-Bulgaria, Hungary, and Poland-had relatively large net external liabilities, primarily in the form of external debt. ${ }^{2}$ In the remaining countries instead the net external position was broadly balanced, and hence substantially stronger than the average position for emerging markets.

\footnotetext{
${ }^{2}$ In Poland, debt forgiveness sharply improved the net external position in 1994.
} 
Given these initial conditions, it was natural to expect substantial net capital flowing to these countries, to take advantage of the high rate of return on capital and catch-up opportunities.

And substantial net capital inflows did indeed take place. During the period 1995-2004, the 11 CEECs ran on average a current account deficit of over $5 \frac{1}{2} 2$ percent of GDP, with a peak average of 8.4 percent in Estonia. ${ }^{3}$ In contrast, the average current account deficit in Latin American countries during this decade was 2.2 percent, while emerging Asian countries ran on average a current account surplus of over 3 percent of GDP. Beyond the spillover effects from the 1998 Russian default, the CEECs were much more insulated from the international financial crises than the other emerging market regions, and experienced lower volatility in net flows.

As a result of this long sequence of current account deficits, the picture regarding net external liabilities in CEECs has changed dramatically (Figure 2). At one extreme, Estonia and Hungary stand out with external liabilities close to the size of the country's GDP. At the other, Slovenia - the country with the highest GDP per capita in the group - maintains a much smaller net external position. It is also interesting to notice that the lower-income countries (i.e. Greece and Portugal) among those that comprised EU membership before the 2004 enlargement (henceforth the EU-15) also experienced a very sharp deterioration in their net external position during the period. In part, it seems, the large current account deficits of the CEEC countries were facilitated by a greater degree of financial integration at both European and global levels that have made it easier to sustain greater external imbalances. ${ }^{4}$

\section{B. International Financial Integration}

The large current account deficits in CEECs were the result of substantial capital inflows (averaging over 10 percent of GDP per annum for the group as a whole, with peaks of 16 percent of GDP in Estonia and Latvia) and nontrivial capital outflows (averaging over $4 \frac{1}{2}$ percent of GDP per annum, with peaks of 8 percent of GDP in Estonia and Latvia). As a result of these developments, the overall degree of international financial integration of the region (measured as the sum of external assets and liabilities, divided by GDP) has more or less doubled during the past decade, increasing from an average of 80 percent of GDP in 1994 to over 160 percent in 2004. It stands at over 250 percent of GDP in Estonia, and over 180 percent of GDP in Croatia, Hungary, and Latvia.

\footnotetext{
${ }^{3}$ A number of papers have focused on current account behavior in CEECs. See, for example, Bussière et al. (2004). Arvai (2005) provides a useful account of the sequencing of capital account liberalization in these countries, plus a review of the literature on capital flows to the CEEC. Lipschitz et al (2002) and Begg et al (2002) analyse the interaction between the exchange rate regime and capital inflows for the CEEC. Buiter and Taci (2003) address the implications of capital account liberalization for financial sector development and financial stability.

${ }^{4}$ See Blanchard and Giavazzi (2002) on the weakening of the link between domestic savings and investment in Europe.
} 
In part, these developments reflects a global trend towards increased cross-border asset trade (see Lane and Milesi-Ferretti, 2006). However, it is also the result of capital account liberalization in the CEEC countries, together with other policy reforms that have increased financial deepening. ${ }^{5}$ While the level of international financial integration remains well below that achieved by the EU-15 group, it is now higher than the median value in other emerging markets and developing countries (Figure 3). ${ }^{6}$

\section{Portfolio Composition}

In the early stages of the transition period, most external liabilities in CEECs were in the form of external debt - total equity liabilities (including FDI and portfolio equity) exceecded 10 percent of GDP at the end of 1994 only in Hungary (17 percent), Czech Republic and Estonia (both around 13 percent). For the region as a whole, the share of equity in total liabilities was around 10 percent. During the past decade, this share has increased very rapidly, fueled by large inflows of foreign direct investment, and now stands at close to 50 percent of total external liabilities, in line with the average in other emerging markets and developing countries, and well above the average in the EU-15 group (Figure 4). ${ }^{7}$

The contrast with the composition of external liabilities for the EU-15 group (and, to a lesser extent, with the portfolio composition of other emerging and developing economies) is stronger if one separates out the share of foreign direct investment in total liabilities (Figure 5). Equity liabilities in CEEC economies almost entirely take the form of FDI, while portfolio equity liabilities represent a much larger share of total liabilities in the EU15 than in the CEEC group.

Looking at the evolution of the external capital structure over time, the data suggest a tapering off of high FDI inflows in some countries in 2003-04 (Czech Republic, Hungary, Slovak Republic), while such inflows have remained high in Estonia and the three EU candidate countries. Looking forward, it is clear that the trend increase in direct investment liabilities (relative to the size of the economy) cannot continue at the same pace, particularly in countries where the ratio implies foreign ownership of a substantial fraction of the

\footnotetext{
${ }^{5}$ On the pattern of capital account liberalization in CEECs, see Arvai (2005).

${ }^{6}$ The sample for other emerging markets and developing countries excludes CEECs as well as 22 industrial countries (the EU-15 plus Australia, Canada, Iceland, Japan, New Zealand, Norway, Switzerland, and the United States).

${ }^{7}$ It is important to appreciate that the FDI category includes investment in real estate (which has been significant in some CEECs), in addition to investment in "productive” enterprises.
} 
domestic capital stock. At end-2004, the stock of FDI relative to GDP was close to 90 percent in Estonia, and over 60 percent in Hungary. ${ }^{8}$

On the external asset side, foreign exchange reserves and other debt assets account for the lion's share of CEECs holdings (Figure 6). In contrast, foreign exchange reserves represent a negligible share of external holdings for the EU-15 group (and other industrial countries, excluding Japan), while equity holdings play an increasingly important role. The pattern for other emerging and developing economies is more similar to the one for the CEEC, but the equity component plays a more important role. ${ }^{9}$

Figure 7 summarizes the net external portfolios of CEECs at the end of 2004: all 11 countries have a negative net equity position, with Estonia's equity liabilities close to 100 percent of GDP on one extreme, and Slovenia's 15 percent of GDP at the other extreme, and 9 of them have a negative net debt position (with the Czech Republic and the Slovak Republic being the exception).

The heavy weighting of FDI in the composition of the CEEC's external liabilities has a number of interesting implications. ${ }^{10}$ First, FDI has attractive risk-sharing properties in that the return to the foreign investor is not fixed but rather depends on the performance of the investment. In this way, by shifting risk to the foreign investor, the CEECs may have been able to run larger current account deficits than would otherwise have been possible, accelerating the convergence process. ${ }^{11}$ Second, to the extent that FDI is also a vehicle for technology transfer, large FDI inflows may also have raised productivity and income growth in the CEEC group. However, as will be analyzed further below in section IV, these positive attributes may come at the cost of a higher return that must be paid to the foreign investor such that a smaller fraction of the income from FDI-financed projects is captured by domestic residents.

\footnotetext{
8 The viable ceiling for FDI depends on the nature of the direct investment. For instance, "greenfield" investments may face less opposition than the acquisition of domestically-owned enterprises or the housing stock. In addition, foreign investors may have a greater risk tolerance for export-platform FDI than marketaccess FDI, with the latter being more heavily dependent on the performance of the host economy.

${ }^{9}$ Even if the aggregate foreign equity assets of the CEEC group are not large, the analysis of the bilateral data in section III shows that some intra-CEEC bilateral equity positions are significant (e.g., the Czech Republic has significant FDI and portfolio equity assets in the Slovak Republic).

${ }^{10}$ See Lane and Milesi-Ferretti (2001) and Faria and Mauro (2005) for further analysis of the factors determining the composition of a country's external liabilities.

${ }^{11}$ Regression analysis shows that over the last decade there is a strong correlation (0.5) between gross equity inflows and current account deficits for emerging markets, whereas the correlation is negligible for advanced economies.
} 
The relatively minor contribution of portfolio equity inflows also merits discussion. Stulz (2006) argues that CEECs generally scores poorly in terms of corporate governance, such that foreign investors face the risk that profits are diverted either by insiders or through political intervention. Accordingly, we may expect that this source of external investment could play a more important role in the future to the extent that the CEEC economies undertake sufficient corporate reforms to match the governance standards in best-practice economies.

On the asset side of the international balance sheet, we may expect that rising income levels and greater trade openness in the CEECs will be associated with greater levels of external FDI and portfolio equity investment than is currently observed. As private-sector portfolios become more internationally diversified, the relative size of foreign exchange reserves is likely to decline.

\section{The Main Stylized Facts: Bilateral Data}

In addition to the aggregate data, it is useful to understand the bilateral composition of the external liabilities of the CEECs. First, the identity of foreign investors may be important in the transmission of international financial shocks-a banking crisis in country $\mathrm{X}$ will have a greater spillover impact on the CEECs, the more important is this group in country X's external asset portfolio. Second, the pricing of CEEC assets depends on the composition of the investor base, since asset returns are more highly correlated between countries that have a tighter degree of financial integration. Third, bilateral investment patterns are important in assessing the valuation impact on the external position of movements in key currencies: a devaluation of some CEEC country against the US dollar will be less important than a devaluation against the euro to the extent that foreign currency debt is mostly denominated in the latter currency.

Tables 1a-1d show the composition of the CEEC's external liabilities across a number of investment categories. We combine data from a number of sources: Eurostat for the composition of FDI, the Bank of International Settlements (BIS) for bank assets and the International Monetary Fund's Coordinated Portfolio Investment Survey (CPIS) for portfolio equity and portfolio debt.

Taking first the composition of FDI in Table 1a, we see that the euro area is collectively the most important source of direct investment for most CEECs. Among the EMU member countries, Austria and Germany are especially significant, with Finland prominent as an investor in the Baltics and Greece important for Bulgaria and Romania. Similar to Finland, Denmark and Sweden also loom large as direct investors in the Baltics. The United Kingdom and United States are also important investors in the Central European countries but the CEEC group is relatively under-represented in the FDI portfolios of these countries. Finally, the scale of intra-CEEC direct investment is worth noting, being especially important for Croatia, Latvia, and Lithuania. 
We turn to the composition of portfolio equity liabilities in Table 1b. In contrast to the FDI case, we see that the United States and the United Kingdom are important portfolio equity investors in the major CEECs, while the euro area remains the most important source for the group. (An important exception is that the Czech Republic is the largest portfolio equity investor in the Slovak Republic.)

Table 1c shows the distribution of the liabilities of the CEECs to the banks from the set of the Bank of International Settlements (BIS) reporting countries. The euro area and the United Kingdom are the dominant sources of external bank finance for most of the CEECs, with the United States and other non-European sources taking a trivially-small share. Again, Austria and Germany are the most important investors in the CEEC among the EMU member countries, with Finland prominent for the Baltics and Italy for Bulgaria. Similar to the FDI case, Sweden is most important external investor in the Baltics. Finally, we turn to portfolio debt in Table 1d. In contrast to the portfolio equity case, the euro area is the most important external holder of the portfolio debt securities issued by the CEECs, while Japan, the United Kingdom and the United States are important for some individual countries. (In contrast to the other categories, the data do not indicate that Sweden is an important source of portfolio debt investment for the Baltics).

Taken together, Tables 1a-1d show that geographical proximity is an important driver of direct investment and bank investment in the CEECs, while the relative stability of the currencies of the CEECs against the euro may help explain the pre-eminence of the euro area as a source of portfolio debt investment. The main non-European financial linkage is in terms of portfolio equity investment-this is the sole category in which the United States takes a prominent role as an external investor in the CEECs.

An interesting question for future research is the extent to which the heavy dominance of intra-European financial cross-holdings can be explained by trade ties together with geographical and cultural proximity, and whether the institutional environment seems to matter above and beyond these factors. ${ }^{12}$ In particular, it would be illuminating to know how EU membership (or the prospect thereof) and, in addition, ultimate entry into EMU affects the allocation decisions of investors.

We turn to a (partial) view on the currency composition of external debt in Table 2, which reports the currency denomination of the international bonds issued by CEECs, as well as the

\footnotetext{
${ }^{12}$ Empirical work for a large sample of countries suggests that these linkages indeed explain a large proportion of bilateral variation in investment patterns (see, for example, Lane and Milesi-Ferretti 2004). The smaller number of observations for the CEECs limit the extent to which different hypotheses can be separately identified for this group.
} 
relative importance of these bond issues in total external debt. ${ }^{13}$ Most international bonds are denominated in euro, with the dollar the second most important currency and the yen and sterling taking a non-trivial share for only a couple of countries. The prominence of the euro in the foreign-currency debt of these countries implies that the bilateral exchange rates of the CEECs vis-à-vis the euro are an important factor in determining the stability and dynamics of their external debt positions. However, a comprehensive view on the effects of exchange rate changes on the debt burden would require additional data on the currency of denomination of external debt - as shown in the last column of Table 2, international bonds represent only a fraction of total debt liabilities for CEECs, the other components being foreign-owned debt securities issued domestically, as well as loans, deposits, and trade credits. ${ }^{14}$

\section{CAPital Flows And External AdJustment}

The previous section has documented the growing recourse to foreign savings in CEECs. Clearly, a country's net external liabilities - relative to the overall size of the economycannot grow without bound. In this section we ask what is the size of the "external adjustment" in CEECs needed to stabilize net external liabilities over the medium term. It is well known that the answer to this question depends on the accumulated stock of external liabilities, the cost of servicing them, and the rate of growth of the domestic economy. However, in a world with increasing international financial integration, the cost of external finance depends on the structure of the external portfolio. We therefore show the key relations between net external position, the current account, the trade balance, and the rates of return on the external portfolio, and present simple examples on the needed size of external adjustment for CEECs.

\section{A. An Accounting Framework ${ }^{15}$}

The change in the net foreign asset position $B$ can be written as follows:

$$
B_{t}-B_{t-1}=C A_{t}+K G_{t}+\mathrm{E}_{t}
$$

where $B_{t}$ is the net foreign asset position, $C A_{t}$ is the current account balance, $K G_{t}$ is the capital gain or loss on net foreign assets (equal to the change in stocks minus the underlying

\footnotetext{
${ }^{13}$ These countries also issue debt securities in their home financial markets, which are typically denominated in the domestic currency. Table 2 also does not address the currency composition of bank lending to these countries.

${ }^{14}$ Devereux and Lane (2003) provide extensive empirical evidence on the connection between bilateral financial linkages and bilateral exchange rate volatility. See also Lane and Milesi-Ferretti (2005a) for an extensive discussion of the implications of foreign-currency debt for exchange rate policy.

${ }^{15}$ This section draws on Lane and Milesi-Ferretti (2005b).
} 
flows) and the term $E_{t}$ includes factors such as capital account transfers (the so-called capital account balance) and errors and omissions that drive a wedge between a country's current account and net inflows of capital.

Indicating ratios to GDP with lower-case letters, we can express (1) as follows:

$$
b_{t}-b_{t-1} \equiv c a_{t}+\frac{K G_{t}}{Y_{t}}-\frac{g_{t}+\pi_{t}}{\left(1+g_{t}\right)\left(1+\pi_{t}\right)} b_{t-1}+\varepsilon_{t}
$$

where $g_{t}$ is the growth rate of real GDP, $\pi_{t}$ is the inflation rate, and the term $\varepsilon$ includes the ratio of capital transfers and errors and omissions to GDP. ${ }^{16}$ Disregarding the latter term, as well as capital gains, ${ }^{17}$ we obtain a simple equation relating the current account balance needed to stabilize the net external position to the outstanding external position and the nominal rate of growth of the economy: $c a^{S S} \approx-\left(g_{t}+\pi_{t}\right) b^{S S}$. For example, in a country running a current account deficit of 5 percent of GDP and growing at 8 percent in nominal terms (5 percent real growth and 3 percent inflation), net external liabilities would stabilize at just over 60 percent of GDP. The equation above makes it clear that a growing country can sustain a 'permanent' current account deficit, and that this deficit can be larger, the larger the growth rate and the larger the stock of external liabilities that the country will service in the long run.

Clearly, if the country starts from a level of external liabilities below 60 percent, a constant current account balance with growing external liabilities will imply an underlying improvement in the trade balance that offsets the higher interest bill associated with the increasing liabilities. Indeed, the current account $C A_{t}$ equals the sum of the balance on goods, services, and current transfers $B G S T_{t}$ and the investment income balance $i_{t}^{A} A_{t-1}-i_{t}^{L} L_{t-1}$, where $A$ and $L$ are external assets and liabilities, respectively, and $i_{t}^{A}, i_{t}^{L}$ are the nominal yields on these assets and liabilities. ${ }^{18}$ We can then express equation (2) as follows:

\footnotetext{
${ }^{16}$ If we measure net foreign assets in domestic currency, the effects on the stock position of changes in the exchange rate vis-à-vis the dollar or the euro will be captured by the capital gains term $K G$. In this case, $\pi_{t}$ in equation (2) is the inflation rate in domestic currency. If instead we measure net foreign assets in foreign currency, $\pi_{t}$ is the inflation rate in dollars or euros.

${ }^{17}$ In order to disregard capital gains we need to assume that the exchange rate is broadly stable in nominal terms vis-à-vis the relevant foreign benchmark (the euro or the dollar).

${ }^{18}$ We incorporate international labor income in the term BGST.
} 


$$
b_{t}-b_{t-1} \equiv b g s t_{t}+\frac{i_{t}^{A} A_{t-1}-i_{t}^{L} L_{t-1}+K G_{t}}{Y_{t}}-\frac{g_{t}+\pi_{t}}{\left(1+g_{t}\right)\left(1+\pi_{t}\right)} b_{t-1}+\varepsilon_{t}
$$

The second term on the right-hand-side of equation (3) captures the effect of nominal returns on external assets and liabilities on the dynamics of the external position. To see this more clearly, define $\mathrm{kg}_{t}^{A}\left(\mathrm{~kg}_{t}^{L}\right)$ as the ratio of the capital gain on external assets (liabilities), measured in domestic currency, to the outstanding stock of external assets (liabilities) at the beginning of the period, so that $k g_{t}^{A} A_{t-1}-k g_{t}^{L} L_{t-1}=K G_{t}$. Then the real rate of return on foreign assets, measured in domestic currency, will equal $r_{t}^{A}=\frac{1+i_{t}^{A}+k g_{t}^{A}}{1+\pi_{t}}-1$, and an analogous definition will hold for the return on foreign liabilities $r_{t}^{L}$. We can re-write (3) as follows: 19

$$
b_{t}-b_{t-1} \equiv b g t_{t}+\frac{r_{t}^{A}-g_{t}}{1+g_{t}} a_{t-1}-\frac{r_{t}^{L}-g_{t}}{1+g_{t}} l_{t-1}+\varepsilon_{t}
$$

When the returns on assets and liabilities are the same $\left(r^{A}=r^{L}\right)$, equation (3) becomes the familiar debt accumulation equation $b_{t}-b_{t-1} \approx b g s t_{t}+\left(r_{t}-g_{t}\right) b_{t-1}$. That is, if a country is a net debtor $(b<0)$ and the rate of return exceecds the growth rate $(r>g)$ a trade surplus is needed to ensure that the ratio of external liabilities to GDP does not grow without bounds. In the more general case in which $r^{A} \neq r^{L}$, equation (4) shows that differences in rates of return between external assets and liabilities will have an importance that is proportional to the scale of the country's international balance sheet. For example, if the total stock of external assets and liabilities is of the order of 100 percent of GDP, and a country pays a rate of return on its liabilities which exceeds the return on assets by 100 basis points, the trade surplus necessary to stabilize the net external position will be 1 percentage point of GDP larger than in the absence of any return differential. ${ }^{20}$ The increase in international financial integration for CEECs documented in the previous section highlights the increasing role that rates of return on the external portfolio play in explaining the evolution of the external position.

\footnotetext{
${ }^{19}$ The same equation can be written using real rates of return in dollars (or euros), rather than domestic currency, using the equivalence $1+r_{t}^{\$}=\left(1+r_{t}\right)\left(1+s_{t}\right)$ where $s_{t}$ is the rate of real domestic-currency appreciation vis-à-vis the U.S. dollar.

${ }^{20}$ The experience of the United States during the past 4 years shows very clearly the importance of rate of return differentials in explaining the evolution of the net external position. Despite having run very large trade deficits, the United States' external position has remained broadly stable since the end of 2001, thanks to sizable excess returns on external assets relative to external liabilities (Lane and Milesi-Ferretti, 2005a).
} 
We can further decompose total assets and liabilities into their "debt" and "equity" components, with the latter including portfolio equity and foreign direct investment holdings:

$$
b_{t}-b_{t-1} \equiv b g s t_{t}+\frac{r_{t}^{E Q A}-g_{t}}{1+g_{t}} a_{t-1}^{E Q}+\frac{r_{t}^{D A}-g_{t}}{1+g_{t}} a_{t-1}^{D}-\frac{r_{t}^{E Q L}-g_{t}}{1+g_{t}} l_{t-1}^{E Q}-\frac{r_{t}^{D L}-g_{t}}{1+g_{t}} l_{t-1}^{D}+\varepsilon_{t}
$$

where the superscript $E Q$ and $D$ identify the debt and equity components of external assets and liabilities, as well as their respective rates of return. Several factors can account for differences in rates of return between external assets and liabilities. ${ }^{21}$ In larger advanced economies, assets tend to be denominated in foreign currency and liabilities mostly in domestic currency. Consequently, an unexpected exchange rate depreciation (not reflected in ex-ante interest differentials) will increase the domestic-currency rate of return on external assets and hence improve the net foreign asset position. In contrast, for emerging markets that are net debtors and whose external liabilities are primarily denominated in foreign currency, a real exchange rate depreciation raises the domestic-currency burden of foreign liabilities. For CEECs, external assets are typically denominated in foreign currency, while the equity component of external liabilities (FDI and portfolio equity) is domestic-currencydenominated. $^{22}$ Therefore the implications of an exchange rate depreciation for the value of the external position is ambiguous - it is likely to be negative for countries with a large stock of foreign-currency-denominated external debt, but it can be positive is the country's foreign assets exceecd foreign-currency debt liabilities. ${ }^{23}$ More generally, differential changes in asset prices (for example, in stock prices) across countries will tend to drive a wedge between returns on external assets and liabilities.

\section{B. Implications for the Trade Balance}

Equation (5) can be used, together with projections for medium-term rates of return and growth rates, to calculate the level of the trade balance (inclusive of transfers and remittances) that would stabilize the net external position, for a given structure of the external portfolio. We undertake this exercise for the CEECs, taking as starting point the external position and the structure of the external portfolio as of the end of 2004. We should point out at the outset that there is no presumption that external liabilities should be stabilized at the current level. Indeed, in some cases the current level is already very high by international standards, and a decline over the medium term would reduce external vulnerabilities.

\footnotetext{
${ }^{21}$ See also the extended discussion in Lane and Milesi-Ferretti (2005a).

${ }^{22}$ By the latter, we mean that the foreign-currency returns on FDI and portfolio equity liabilities will typically be highly correlated with currency movements.

${ }^{23}$ An important feature of CEEC economies is the tendency to experience trend real appreciation for BalassaSamuelson reasons (Lipschitz et al., 2002; Begg et al., 2003).
} 
Our projections are constructed as follows.

- For output growth we take the average growth rate over 2005-10 as projected in the IMF's World Economic Outlook;

- For foreign direct investment and portfolio equity investment in the country, our baseline assumption is that the rate of return will move together with the growth rate of the economy. This assumption reflects the risk-sharing role of equity investment-if the country does well overall, foreign investors are going to reap higher rates of return and vice versa. For simplicity, we assume that the average return on equity can be represented by a constant spread over the growth rate (in our calculations, we set the spread at 100 basis points).

- For foreign debt liabilities, the rate of return is assumed to be equal to the projected interest rate on long-term bonds in the euro area plus a spread. This spread can be interpreted as combining the effects of a default risk premium on euro-denominated bonds and a default risk premium plus currency risk premium on domestic-currency bonds. For the Baltic countries, we set the spread at 50 basis points; for the other countries, the benchmark spread is 150 basis points although we also report results for the alternative scenario in which the spread for all countries is set at 50 basis points.

- $\quad$ For foreign direct investment and portfolio investment abroad, the rate of return is assumed to exceed the world growth rate by 100 basis points, for reasons analogous to those mentioned in the discussion of returns on equity liabilities;

- $\quad$ Finally, the rate of return for debt assets abroad is assumed to be equal to the projected interest rate on euro bonds.

One should note that world interest rates are assumed to increase over the medium term from their currently low levels. Ceteris paribus, this will imply that the investment income balance of countries with net debt liabilities (the large majority of CEECs—see figure 7) is projected to deteriorate over the medium term.

Table 3 provides the data on external assets and liabilities (as in equation (5)) and Table 4 gives the liabilities-stabilizing trade balance under the baseline assumptions on returns, as well as under two alternative scenarios: one with lower spreads on external debt, and the other with lower domestic GDP growth. The average trade balance during the period 2001-2004 is also provided, so as to get a rough idea of the trade adjustment necessary over the medium term.

One first interesting result is that the trade surplus needed to stabilize the net external position at its current level shows relatively small cross-country differences, despite very large differences in the net external position. This is due to the fact that the difference between the rates of return and the growth rate is generally small, such that the dynamics of 
the external position is largely driven by the trade balance. Under these assumptions, the necessary adjustment in the trade balance is particularly large for countries that are running large trade deficits, rather than necessarily for countries with large external liabilities.

A second key implication of the analysis is that the necessary shift in the trade balance is very substantial in a number of CEECs, particularly for Baltic countries, Bulgaria, and Romania. Over the medium term, the exports of these countries need to outpace imports to ensure that external liabilities are stabilized relative to the size of the economy.

A third implication is that lower spreads on external debt (column (2)) reduce the required trade surplus, particularly for countries with large external debt liabilities such as Croatia-

a 100 basis points reduction in the spread reduces the needed trade surplus by 0.8 percent of GDP. In contrast, higher growth has a modest impact on the needed trade surplus — while it implies more favorable debt dynamics, it also raises the return on FDI and equity liabilities, which are an important part of total external liabilities. Of course, this is just a manifestation of international risk sharing principles - if CEECs were relying more heavily on foreigncurrency-denominated external debt, the impact of lower growth on the needed trade surplus would be larger.

Would trade balance reversals of this order of magnitude imply a massive outflow of capital from CEEC countries? Clearly not. Given the large negative external position, the investment income balance would remain in substantial deficit, consequently so would be the current account. Because of the projected worsening of the investment income balance for some of the CEECs, relative to its current levels, the implied shift in the current account needed to stabilize the external position is smaller than the shift in the trade balance.

\section{CONCLUding REMARKS}

The CEECs are an excellent case study in understanding the potential gains from international financial integration. The large current account deficits of the last decade have plausibly facilitated a more rapid convergence rate in output and living standards than would otherwise have been possible. Moreover, much of the capital inflows have taken the form of FDI, which provides attractive risk-sharing and technological benefits. Looking forward, the prospect of deeper integration with other EU-member countries for those CEECs that have already joined the EU, plus the accession prospects for Bulgaria, Croatia, and Romania, could well bring additional benefits-lower perceived risk, stronger demand for exports, and higher labor remittances from workers moving to richer countries. The long-overdue recovery in the euro area would also provide a much needed boost to external demand, thus helping external sustainability.

On the other hand, the stock of external liabilities is high by international standards in several CEECs, and the needed adjustment in the trade balance over the medium term is substantial, a task which is not made easier by the limited room for exchange rate correction. In addition, 
these countries have benefited from exceptionally favorable external financing conditions in recent years, as demand for external finance has waned in other emerging markets that are running large current account surpluses, world interest rates remain very low, and emerging market debt spreads are at record low levels. While Slovenia has maintained limited external imbalances throughout the period, and Poland and (to an extent) the Czech Republic have reduced their current account deficits in recent years, most other countries have seen a significant expansion in their current account deficits from 2002 onwards. For this reason, any sharp adjustment in the external balance could be quite disruptive in terms of reversing this momentum. Looking forward, policymakers need to ensure the resilience of these countries' external positions to a less favorable international financial markets environment.

Our illustrative calculations have highlighted how the adjustment path for the trade balance in future years depends on the rates of return on FDI investments in the CEECs-the higher is the profitability of FDI, the larger is the trade surplus that is required. However, by the same token, a high return on FDI is likely to be associated with a high rate of domestic output growth, making repayments more affordable. 


\section{REFERENCES}

Arvai, Zsofia, 2005, “Capital Account Liberalization, Capital Flow Patterns, and Policy Responses in the EU's New Member States,” IMF Working Paper No. 05/213 (Washington: International Monetary Fund).

Begg, David, Barry Eichengreen, László Halpern, Jürgen von Hagen, and Charles Wyplosz, 2003, "Sustainable Regimes of Capital Movements in Accession Countries,” CEPR Policy Paper No. 10 (London: Centre for Economic Policy Review).

Bertaut, Carol, and Linda Kole, 2004, “What Makes Investors Overweight or Underweight? Explaining International Appetites for Foreign Equities,” Federal Reserve Board Bulletin, No. 90, No. 1 (Winter), pp. 19-31.

Blanchard, Olivier, and Francesco Giavazzi, 2002, "Current Account Deficits in the Euro Area. The End of the Feldstein Horioka Puzzle?” Brookings Papers on Economic Activity 2, pp. 147-202.

Buiter, Willem, and Anita Taci, 2003, “Capital Account Liberalization and Financial Sector Development in Transition Countries,” in Capital Liberalization in Transition Countries: Lessons from the Past and for the Future, ed. by Age F. P. Bakker and Bryan Chapple (Cheltenham: Elgar) pp. 105-41.

Bussière, Matthieu, Marcel Fratzscher, and Gernot J. Muller, 2004, “Current Account Dynamics in OECD and EU Acceding Countries-An Intertemporal Approach,” ECB Working Paper No. 311 (Frankfurt: European Central Bank).

Devereux, Michael B., and Philip R. Lane, 2003, "Understanding Bilateral Exchange Rate Volatility,” Journal of International Economics, Vol. 60, No. 1, pp. 109-32.

Faria, Andre, and Paolo Mauro, 2005, "Institutions and the External Capital Structure of Countries,” IMF Working Paper No. 04/236 (Washington: International Monetary Fund).

Lane, Philip.R., and Gian Maria Milesi-Ferretti, 2001, "External Capital Structure: Theory and Evidence,” in The World's New Financial Landscape: Challenges for Economic Policy, ed. by H. Siebert (New York: Springer), pp. 247-84.

— , 2003, “International Financial Integration,” IMF Staff Papers, Vol. 50 (Special Issue), pp. 82-113.

_ (Washington: International Monetary Fund). 
—_, 2005b, “A Global Perspective on External Positions, ” IMF Working Paper 05/61 (Washington: International Monetary Fund).

_ _ 2006, "The External Wealth of Nations Mark II: Revised and Extended Estimates of Foreign Assets and Liabilities, 1970-2004,” IMF Working Paper 06/69, (Washington: International Monetary Fund).

Lipschitz, Leslie, Timothy Lane, and Alexander Mourmouras, 2002, “Capital Flows to Transition Economies: Master or Servant?” IMF Working Paper 02/11 (Washington: International Monetary Fund).

Obstfeld, Maurice, 2004, “External Adjustment,” Review of World Economics, Vol. 140, No. 4, pp. 541-68.

Stulz, Rene, 2006, “Financial Globalization, Corporate Governance and Eastern Europe,” NBER Working Paper No. 11912 (Cambridge, Massachusetts: National Bureau of Economic Research). 
Table 1A. Central and Eastern European Countries: Foreign Direct linvestment Sources.

\begin{tabular}{lccccccr}
\hline & EMU & $\begin{array}{c}\text { United } \\
\text { Kingdom }\end{array}$ & $\begin{array}{c}\text { United } \\
\text { States }\end{array}$ & Denmark & Sweden & Switzerland. & CEEC \\
\hline Bulgaria & 87.0 & 5.3 & 5.7 & 1.0 & & & 1.0 \\
Croatia & 81.4 & & 1.8 & 1.1 & & 2.7 & 13.0 \\
Czech Republic & 82.3 & 5.3 & 4.3 & 1.0 & 1.9 & 4.4 & 0.9 \\
Estonia & 47.4 & 0.7 & 1.5 & 3.4 & 46.1 & & 0.8 \\
Hungary & 79.2 & 7.3 & 8.1 & 0.7 & 2.3 & 1.5 & 1.0 \\
Latvia & 25.7 & 1.1 & -0.6 & 15.7 & 44.6 & & 13.5 \\
Lithuania & 23.5 & 0.5 & 2.8 & 34.7 & 24.5 & & 14.0 \\
Poland & 73.1 & 7.4 & 9.3 & 2.9 & 3.8 & 3.1 & 0.3 \\
Romania & 89.4 & 1.3 & 7.7 & 0.4 & & & 1.1 \\
Slovakia & 83.5 & & 8.6 & 0.7 & & 1.4 & 5.8 \\
Slovenia & 95.5 & & 1.6 & 0.0 & & & 3.0 \\
\hline
\end{tabular}

Note: Importance of selected countries as sources of FDI stocks in the Central and Eastern European Countries for 2002. EMU is the European Monetary Union.

Source: Authors's calculations based on Eurostat data.

Table 1B. Central and Eastern European Countries: Sources of Portfolio Equity Investment

\begin{tabular}{lccrrrrr}
\hline & EMU & $\begin{array}{c}\text { United } \\
\text { Kingdom }\end{array}$ & $\begin{array}{c}\text { United } \\
\text { States }\end{array}$ & EFTA & Japan & $\begin{array}{c}\text { CEEC } \\
\end{array}$ & $\begin{array}{c}\text { Rest of } \\
\text { the } \\
\text { World }\end{array}$ \\
\hline Bulgaria & 52.4 & & 5.2 & 20.3 & & 17.5 & 4.6 \\
Czech Republic & 52.1 & 7.0 & 30.8 & 5.4 & 0.2 & 0.8 & 3.8 \\
Slovak Republic & 54.5 & & & 1.9 & & 43.1 & 0.4 \\
Estonia & 67.2 & & 20.7 & 10.2 & 0.3 & & 1.6 \\
Latvia & 54.7 & & 2.6 & 31.1 & & 11.1 & 0.5 \\
Hungary & 43.3 & 12.5 & 35.6 & 6.3 & 0.2 & 0.8 & 1.4 \\
Lithuania & 59.3 & & 0.9 & 33.1 & & 6.8 & 0.0 \\
Croatia & 26.8 & 15.4 & 31.9 & 13.5 & & 7.9 & 4.5 \\
Slovenia & 71.2 & 22.0 & 0.2 & 6.2 & & 0.5 & 0.0 \\
Poland & 50.9 & 8.4 & 29.5 & 7.7 & 0.2 & 1.5 & 1.8 \\
Romania & 42.1 & & 21.7 & 8.9 & & 2.9 & 24.4 \\
\hline
\end{tabular}

Note: Share of source countries in portfolio equity liabilities of the Central and Eastern European Countries. EMU is the European Monetary Union and EFTA is the European Free Trade Area. Source: Authors' calculations from 2004 CPIS data. Some cells are empty for confidentiality reasons. 
Table 1C. Central and Eastern European Countries: Sources of Foreign Bank Assets

\begin{tabular}{lccrrrrr}
\hline & EMU & $\begin{array}{c}\text { United } \\
\text { States }\end{array}$ & $\begin{array}{c}\text { United } \\
\text { Kingdom }\end{array}$ & Sweden & Switzeland & Japan & $\begin{array}{c}\text { Hong } \\
\text { Kong }\end{array}$ \\
\hline Bulgaria & 68.4 & 1.5 & 24.7 & 0.4 & 3.8 & 1.2 & 0.0 \\
Croatia & 85.5 & & 11.2 & 0.0 & 0.9 & 2.4 & 0.0 \\
Czech Republic & 90.5 & 1.7 & 6.9 & 0.1 & 0.7 & 0.1 & 0.0 \\
Estonia & 45.0 & & 6.3 & 47.4 & 0.5 & 0.9 & 0.0 \\
Hungary & 82.0 & 0.3 & 15.5 & 0.1 & 1.0 & 0.9 & 0.2 \\
Latvia & 62.3 & & 3.6 & 32.1 & 1.9 & 0.0 & 0.0 \\
Lithuania & 63.2 & & 2.3 & 33.8 & 0.5 & 0.3 & 0.0 \\
Poland & 81.1 & 2.9 & 10.1 & 1.8 & 1.1 & 2.9 & 0.1 \\
Romania & 71.9 & 3.5 & 20.8 & 1.1 & 1.7 & 1.0 & 0.0 \\
Slovak Republic & 93.0 & & 6.0 & 0.0 & 0.6 & 0.4 & 0.0 \\
Slovenia & 91.8 & & 7.1 & 0.1 & 1.0 & 0.0 & 0.0 \\
\hline
\end{tabular}

Note: Authors' calculations based on Bank of International Settlements locational data for 2004 for the set of reporting countries listed in the table. EMU is the European Monetary Union.

Table 1D: Central and Eastern European Countries: Sources of Portfolio Debt Investment

\begin{tabular}{lccccccc}
\hline & EMU & $\begin{array}{c}\text { United } \\
\text { Kingdom }\end{array}$ & $\begin{array}{c}\text { United } \\
\text { States }\end{array}$ & EFTA & Japan & $\begin{array}{c}\text { CEEC } \\
\text { Rest of } \\
\text { the } \\
\text { World }\end{array}$ \\
\hline Bulgaria & 53.5 & 9.7 & 29.4 & 3.4 & 0.9 & 0.1 & 3.0 \\
Czech Republic & 94.4 & & 0.6 & 2.5 & 0.4 & & 2.1 \\
Slovak Republic & 80.5 & 4.3 & 3.6 & 1.1 & 1.1 & 8.5 & 0.9 \\
Estonia & 70.4 & & 2.3 & 22.0 & 1.6 & 0.6 & 3.1 \\
Latvia & 92.1 & & 0.5 & 0.6 & 0.0 & 4.5 & 2.3 \\
Hungary & 78.1 & 9.2 & 1.9 & 2.8 & 3.7 & 0.7 & 3.6 \\
Lithuania & 78.5 & 8.5 & & 0.9 & 0.4 & 2.4 & 9.3 \\
Croatia & 81.9 & & 6.6 & 2.6 & 5.3 & 1.9 & 1.7 \\
Slovenia & 79.0 & 12.7 & 1.4 & 2.5 & 0.1 & 2.1 & 2.1 \\
Poland & 78.7 & & 9.0 & 2.4 & 7.3 & 1.5 & 1.1 \\
Romania & 72.1 & 20.9 & 1.3 & 1.5 & 0.0 & 1.0 & 3.1 \\
\hline
\end{tabular}

Note: Share of source countries in long-term portfolio debt liabilities of the Central and Eastern European Countries (CEEC). EMU is the European Monetary Union and EFTA is the European Free Trade Area.

Source: Authors' calculations from the 2004 Coordinated Portfolio Investment Survey data. Some cells are empty for confidentiality reasons. 
Table 2. Currency Composition of International Bond Issues

\begin{tabular}{lrrrrrr|r}
\hline & Own & Euro & $\begin{array}{c}\text { US } \\
\text { Dollars }\end{array}$ & $\begin{array}{c}\text { Japan. } \\
\text { Yen }\end{array}$ & $\begin{array}{c}\text { British } \\
\text { Pound } \\
\text { Sterling }\end{array}$ & $\begin{array}{c}\text { Other } \\
\text { curr. }\end{array}$ & $\begin{array}{c}\text { Int'l bonds in percent } \\
\text { of total external debt } \\
(2004)\end{array}$ \\
\hline Bulgaria & & 72.2 & 27.8 & & & & 22.4 \\
Croatia & & 66.0 & 20.1 & 14.0 & & & 31.3 \\
Czech Republic & 3.2 & 86.1 & 10.8 & & & & 15.2 \\
Estonia & & 96.1 & & & & 3.9 & 30.7 \\
Hungary & & 66.0 & 13.4 & 11.4 & 9.3 & & 26.6 \\
Latvia & & 100.0 & & & & & 7.4 \\
Lithuania & 1.3 & 98.7 & & & & & 29.1 \\
Poland & & 68.7 & 17.4 & 4.8 & 2.6 & 6.5 & 17.7 \\
Slovak Republic & 8.0 & 84.3 & 7.7 & & & & 15.2 \\
Slovenia & 5.5 & 93.7 & 0.9 & & & & 14.3 \\
Romania & & 86.6 & 13.4 & & & & \\
\hline
\end{tabular}

Note: Data are for bonds and notes outstanding, 2005. The last column reports total international bond issues as a share of total external debt. Source: Authors' calculations based on data from the Bank of International Settlements. 
Table 3. Composition of Net External Position (in percent of GDP), 2004

\begin{tabular}{lccrrrr}
\hline & $\begin{array}{c}\text { Net foreign } \\
\text { assets }\end{array}$ & $\begin{array}{c}\text { Debt assets } \\
\text { (including } \\
\text { reserves) }\end{array}$ & $\begin{array}{c}\text { Equity } \\
\text { assets }\end{array}$ & $\begin{array}{c}\text { Debt } \\
\text { liabilities }\end{array}$ & $\begin{array}{c}\text { Equity } \\
\text { liabilities }\end{array}$ & $\begin{array}{c}\text { Growth } \\
\text { rate }\end{array}$ \\
\hline Bulgaria & -47.8 & 62.9 & -0.1 & 70.0 & 40.5 & 5.5 \\
Czech Republic & -34.6 & 58.0 & 5.9 & 37.2 & 61.4 & 3.6 \\
Slovak Republic & -37.5 & 54.2 & 5.3 & 50.6 & 46.5 & 4.9 \\
Estonia & -99.7 & 59.6 & 16.3 & 70.7 & 104.9 & 5.8 \\
Latvia & -55.0 & 65.4 & 2.2 & 88.0 & 34.6 & 6.2 \\
Hungary & -96.9 & 35.4 & 6.7 & 64.9 & 74.0 & 3.9 \\
Lithuania & -38.9 & 31.0 & 2.1 & 42.4 & 29.6 & 6.0 \\
Croatia & -64.5 & 54.2 & 7.5 & 84.8 & 41.4 & 4.4 \\
Slovenia & -18.0 & 55.1 & 11.3 & 58.9 & 25.5 & 3.7 \\
Poland & -53.3 & 30.1 & 1.5 & 44.2 & 40.7 & 3.8 \\
Romania & -34.8 & 30.0 & 0.4 & 37.4 & 27.9 & 5.0 \\
\hline
\end{tabular}

Table 4. NFA-Stabilizing Trade Balance

\begin{tabular}{lcccc}
\hline & $\begin{array}{c}\text { Trade balance, pct of GDP } \\
\text { (average 2001-04) }\end{array}$ & \multicolumn{3}{c}{ NFA-stabilizing trade balance } \\
\cline { 3 - 5 } & & Baseline & $\begin{array}{c}\text { Lower debt } \\
\text { spread }\end{array}$ & $\begin{array}{c}\text { Higher } \\
\text { growth }\end{array}$ \\
\hline Bulgaria & -5.2 & 1.2 & 0.5 & 1.2 \\
Czech Republic & -1.3 & 1.3 & 1.0 & 1.6 \\
Slovak Republic & -3.6 & 1.3 & 0.8 & 1.4 \\
Estonia & -4.4 & 1.1 & 1.1 & 1.2 \\
Latvia & -8.1 & -0.1 & -0.1 & -0.3 \\
Hungary & -1.9 & 1.2 & 0.5 & 0.9 \\
Lithuania & -3.6 & 0.1 & 0.1 & 0.0 \\
Croatia & -2.4 & 1.0 & 0.2 & 0.8 \\
Slovenia & -0.1 & 0.9 & 0.3 & 1.0 \\
Poland & -0.8 & 0.9 & 0.4 & 0.7 \\
Romania & -3.8 & 0.6 & 0.3 & 0.6 \\
\hline
\end{tabular}

Note: trade balance defined as sum of balance on trade in goods and services, plus net current transfers and capital account transfers, in percent of GDP. The NFA-stabilizing trade balance is the ratio of the trade balance to GDP that stabilizes the ratio of net foreign assets (NFA) to GDP. Baseline assumptions: the rate of return on equity liabilities is equal to the economy's growth rate plus 100 basis points. For all countries, the rate of return on debt assets is equal to 2.5 percent in real terms, the rate of return on equity assets is equal to the world's growth rate (4.3 percent) plus 100 basis points, and the spread on debt liabilities is equal to 150 basis points over debt assets. Lower spread assumption: debt spread reduced to 50 basis points.

Higher growth assumption: growth (and the return on equity liabilities) higher by 1 percent in all countries. 
Figure 1. Net External Position, Developing Countries and Emerging Markets, 1994

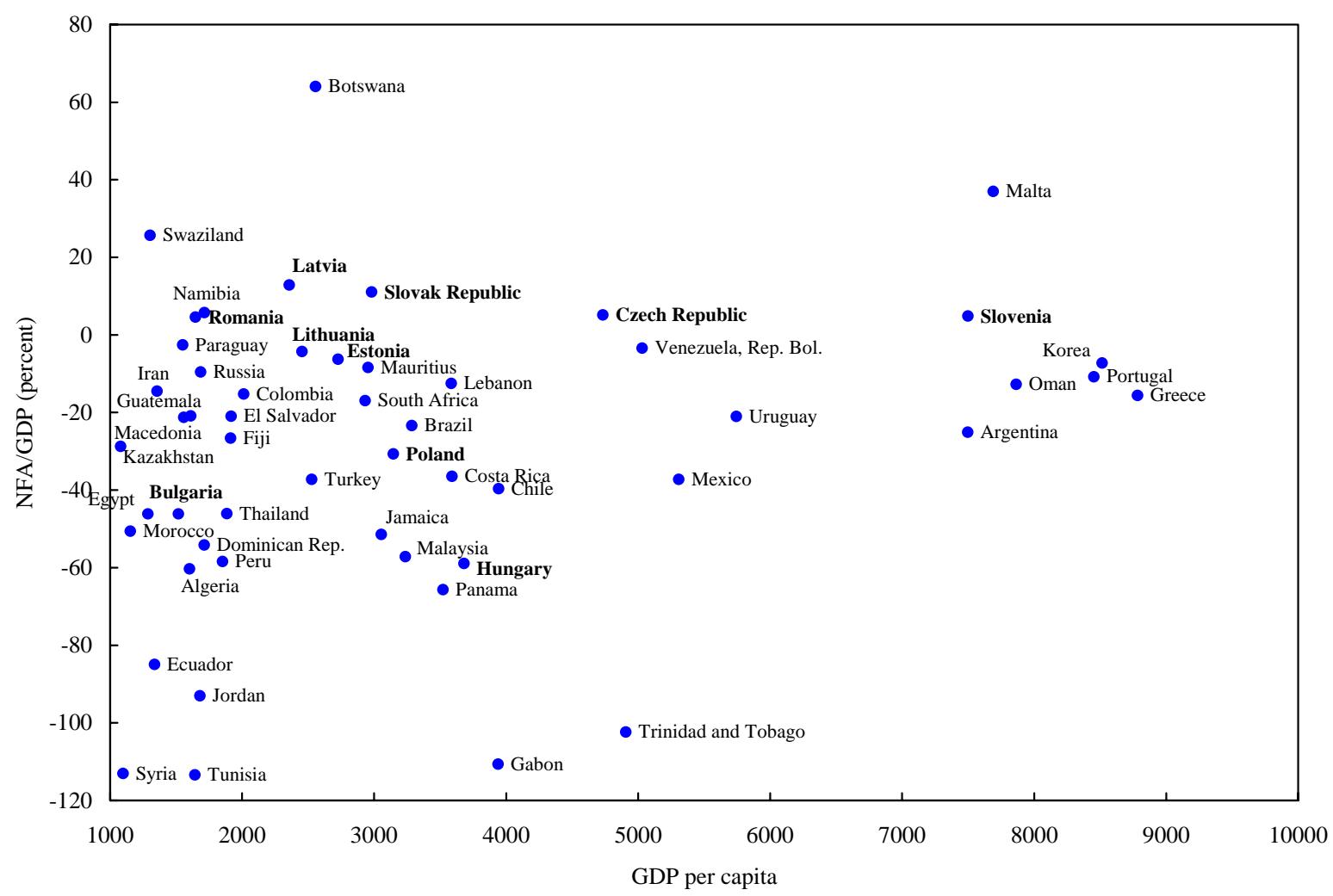


Figure 2. Net External Position, Developing Countries and Emerging Markets, 2004

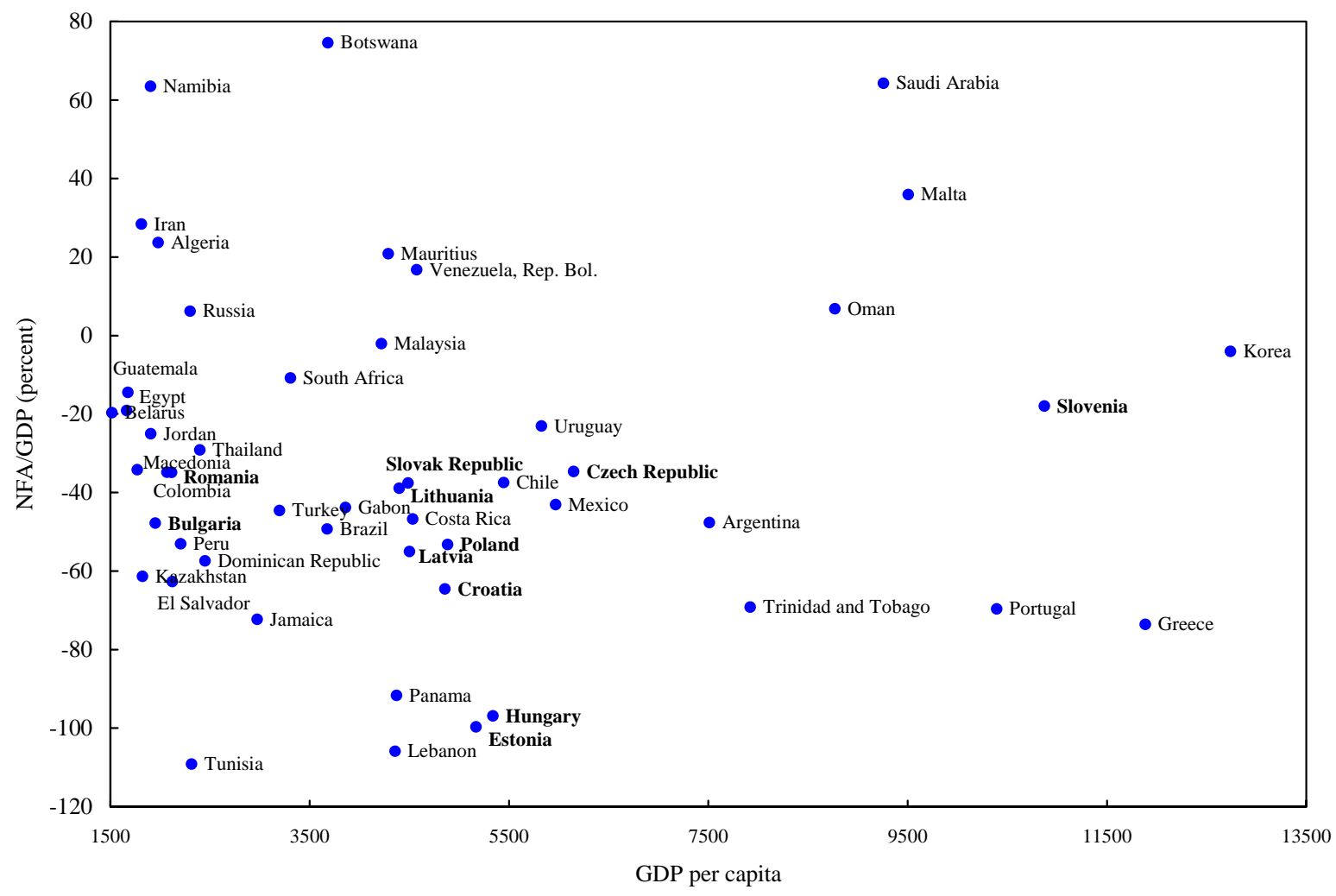


Figure 3. International Financial Integration:

Central and Eastern European Countries, EU-15 Group, and Other Emerging Markets, 1993-2004

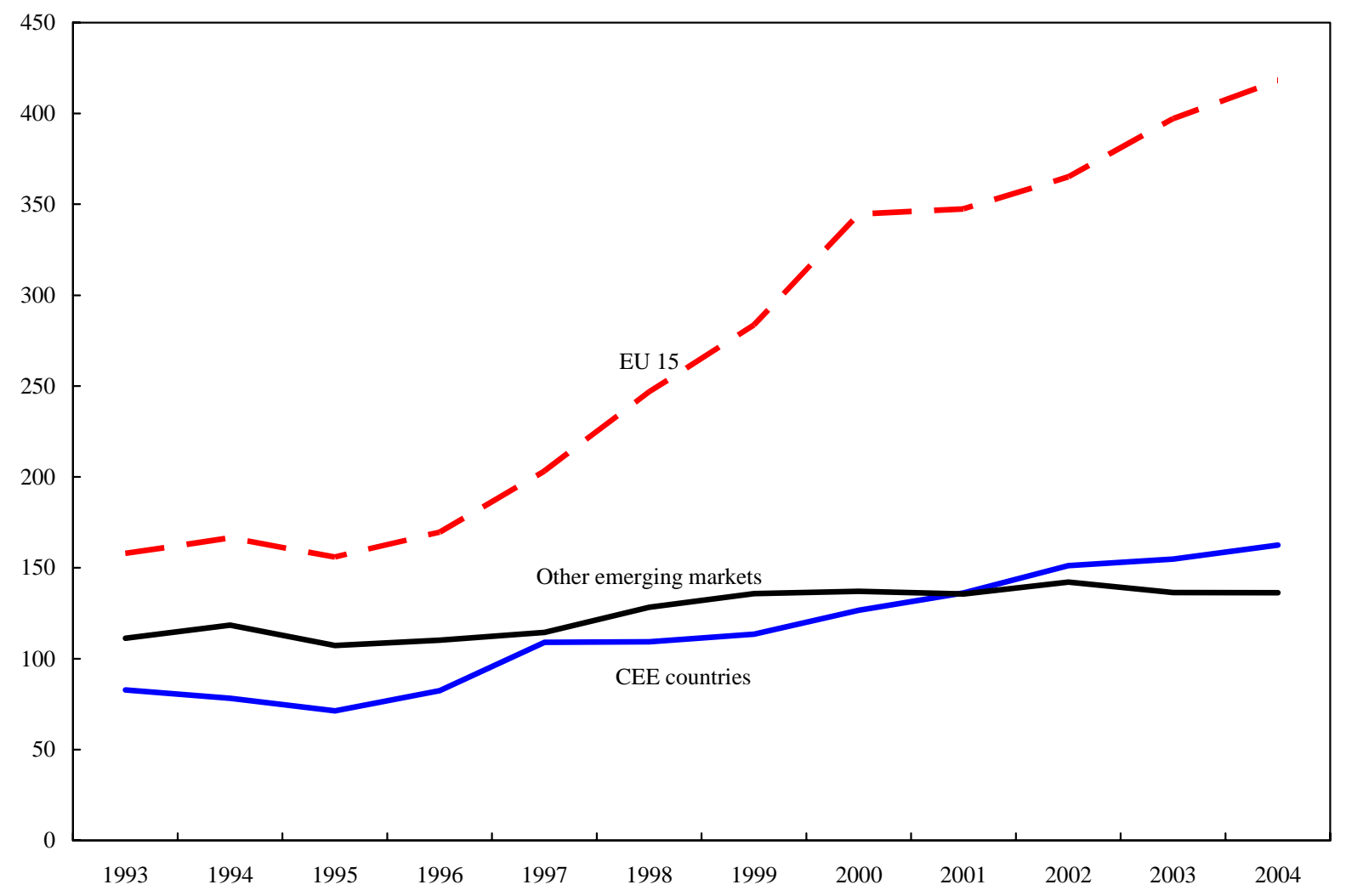


Figure 4. Composition of External Liabilities:

Share of Total Equity Liabilities, 1993-2004

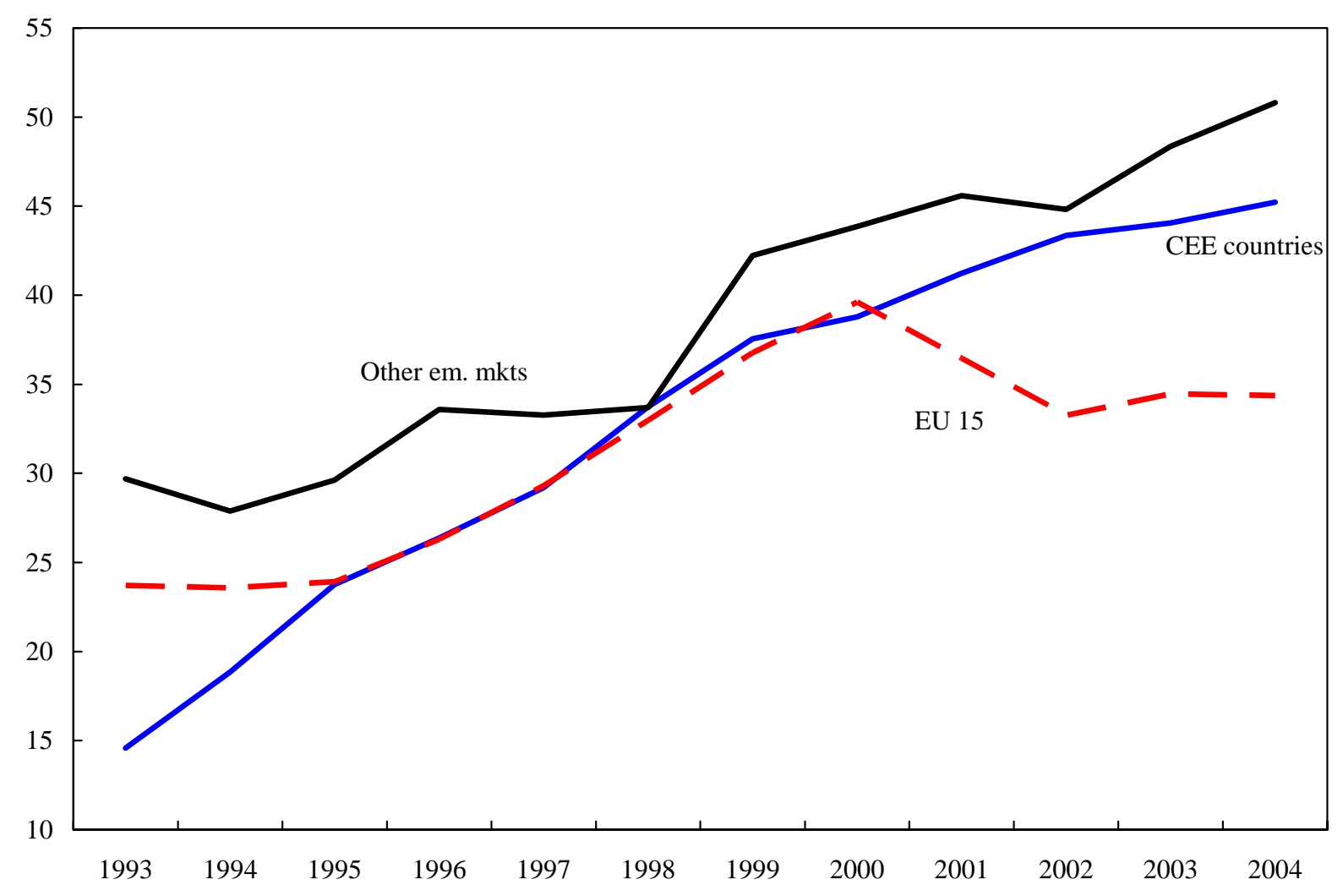


Figure 5. Composition of External Liabilities:

Share of Foreign Direct Investment Liabilities, 1993-2004

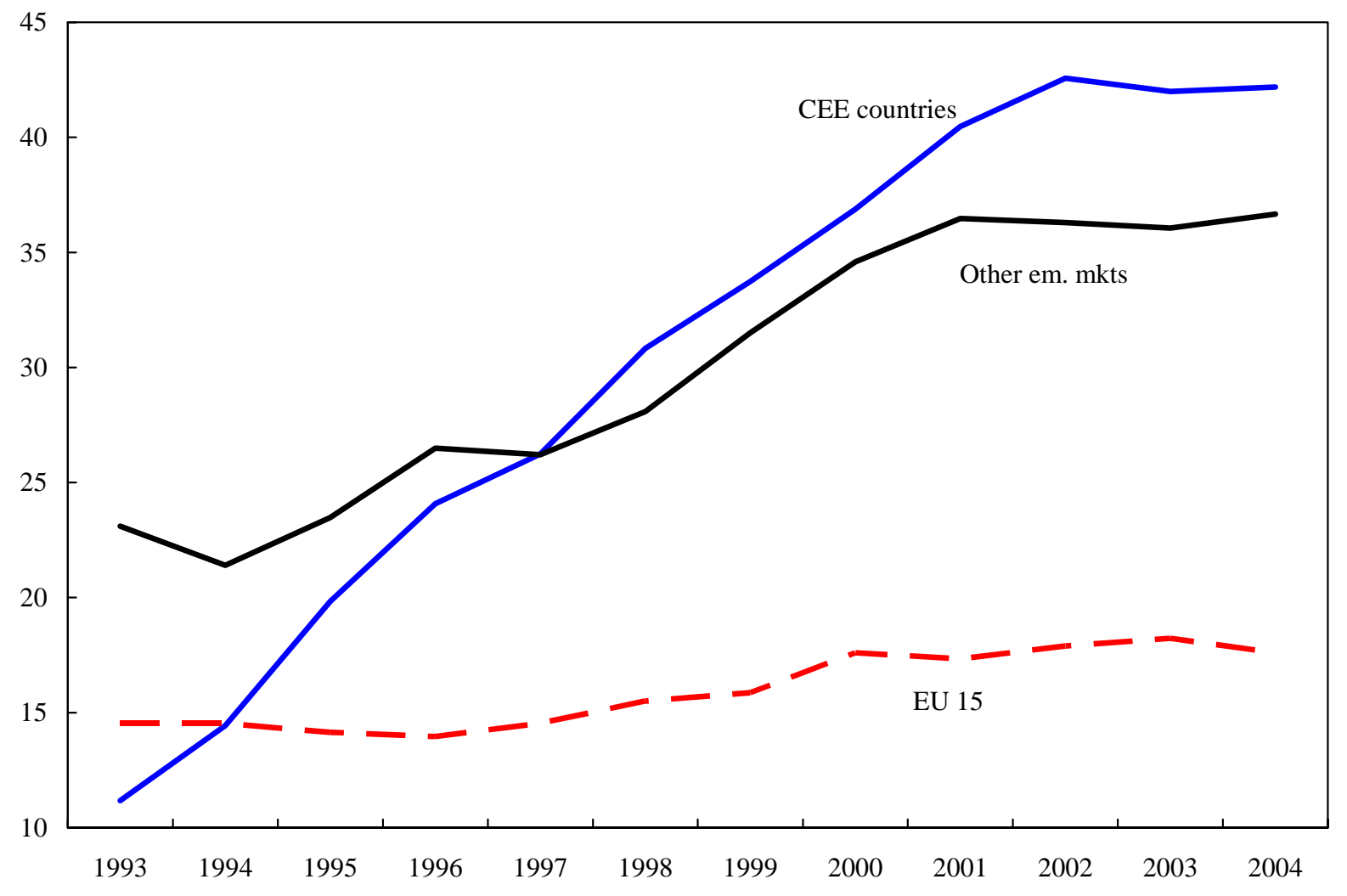


Figure 6. Composition of External Assets:

Central and Eastern European Countries, EU15, and Other Emerging and Developing Economies, 1993-2004
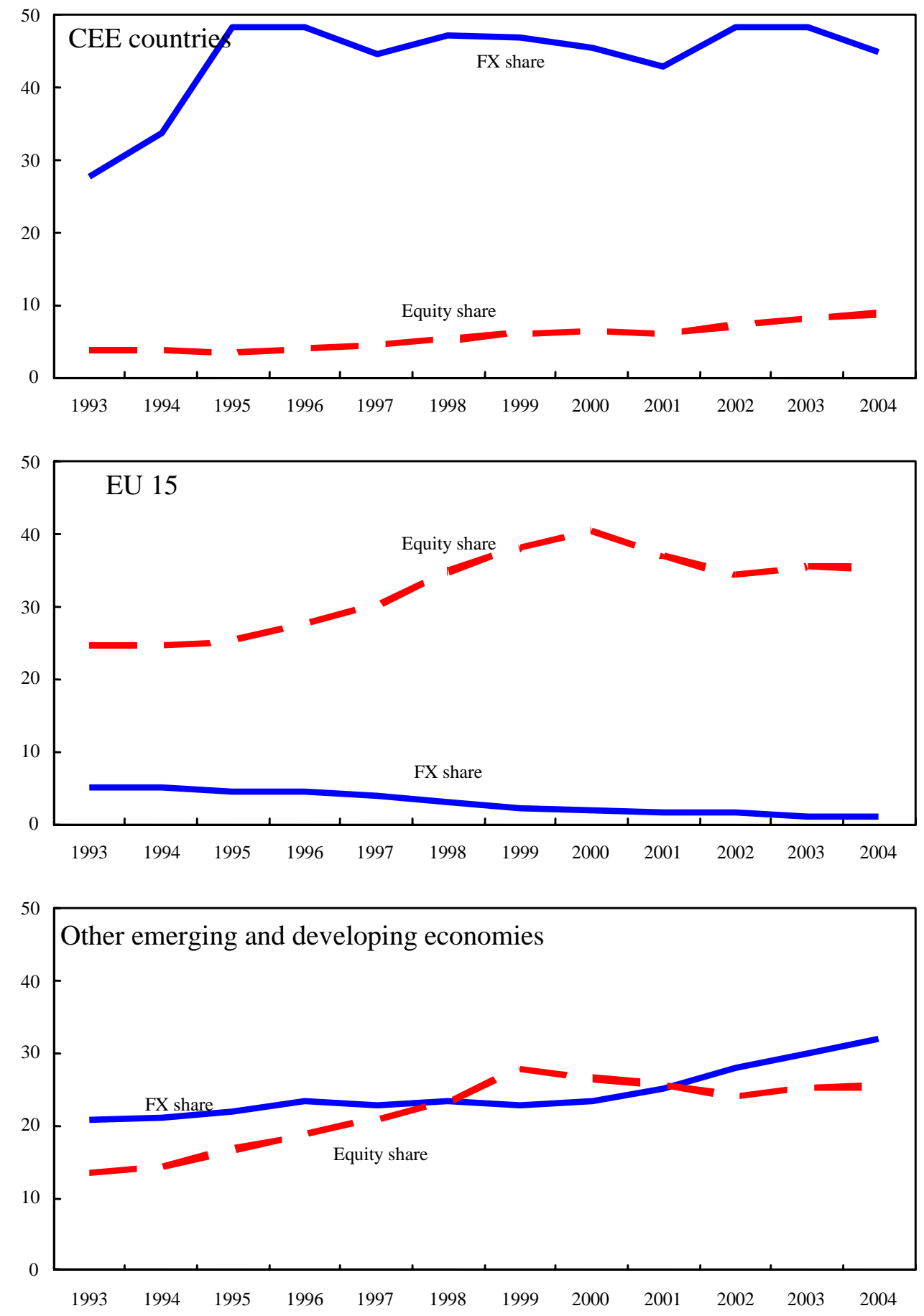

Note: FX share is the ratio of foreign exchange reserves to total external assets (in percent); equity share is the ratio of FDI and portfolio equity assets to total external assets in percent). 
Figure 7. Central and Eastern European Countries: Net Equity and Net Debt Position, 2004

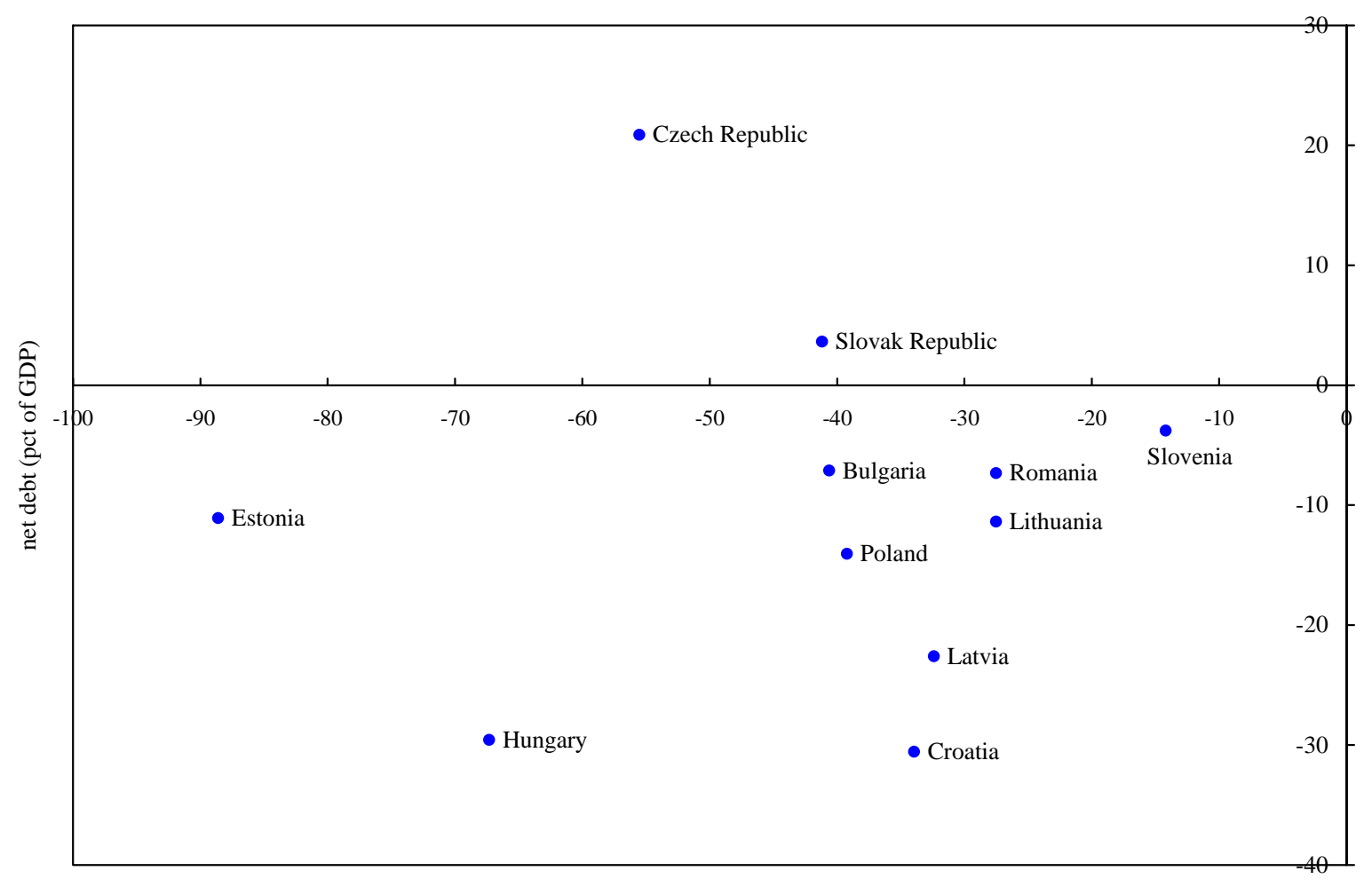

net equity (pct of GDP) 